\title{
EDUKACJA PRZEDPORODOWA JAKO PRZYGOTOWANIE KOBIETY DO MACIERZYŃSTWA
}

\section{THE ANTENATAL EDUCATION IN PREPARING WOMEN FOR MATERNITY}

\author{
Agnieszka Araszkiewicz, a , Katarzyna Plagens-Rotman², b \\ ${ }^{1}$ Szkoła Rodzenia „Położna z Sercem” Poznań, Uniwersytet Medyczny im. Karola Marcinkowskiego w Poznaniu \\ ${ }^{2}$ Państwowa Wyższa Szkoła Zawodowa im. Hipolita Cegielskiego w Gnieźnie \\ ${ }^{a}$ https://orcid.org/0000-0001-9464-7195 \\ ${ }^{\mathrm{b}} \mathrm{https}: / /$ orcid.org/0000-0001-7646-7430
}

DOI: https://doi.org/10.20883/pielpol.2020.20

\begin{abstract}
STRESZCZENIE
Podczas edukacji przedporodowej wobec kobiety oraz całej jej rodziny stosuje się działania zmierzające do kształtowania prawidłowych zachowań zdrowotnych. Szkoły rodzenia są rekomendowane przez Polskie Towarzystwo Ginekologiczne, Polskie Towarzystwo Położnych czy Fundację „Rodzić po ludzku” jako jeden ze sposobów przygotowania przyszłych rodziców do porodu i opieki nad dzieckiem.

Celem pracy jest przybliżenie zagadnień poruszanych podczas edukacji przedporodowej w szkole rodzenia oraz na wizytach prowadzonych przez położną środowiskowo-rodzinną w Polsce na podstawie wybranych publikacji.

Przekazywanie wiadomości o możliwości uczestniczenia w edukacji przedporodowej skutkuje zwiększeniem liczby kobiet, a przy okazji też przyszłych ojców przygotowujących się w sposób programowy do porodu i podejmowania prawidłowych ról rodzicielskich.
\end{abstract}

SŁOWA KLUCZOWE: położna, poród, ciąża, macierzyństwo, edukacja przedporodowa.

\section{Wprowadzenie}

Współczesna edukacja przedporodowa przygotowuje kobietę oraz coraz częściej całą jej rodzinę do okresu okołoporodowego i pełnego macierzyństwa, skupiając się przede wszystkim na powrocie do fizjologicznych procesów, przebiegających przy ograniczeniu do minimum niezbędnej medykalizacji [1]. Na zdrowie kobiety oraz jej dziecka wpływają zachowania z całego okresu ciąży, porodu i połogu, dlatego tak ważne jest dość wczesne rozpoczęcie prowadzenia edukacji mającej na celu przygotowanie kobiety do nowej życiowej roli [2-5].

Bezpłatną edukację przedporodową kobieta ma możliwość rozpocząć od 21. tygodnia ciąży, spotykając się z położną 1 raz w tygodniu do osiągnięcia przez nią 31. tygodnia ciąży, a następnie ma możliwość odbywania spotkań 2 razy w tygodniu, aż do momentu porodu [6]. Takie spotkania mogą odbywać się indywidualnie

\begin{abstract}
During the antenatal education for a woman and her whole family, a huge group of activities aimed at shaping proper health behaviors is applied.

Antenatal classes are recommended by the Polish Gynecological Society, Polish Midwives Association or Foundation „Childbirth with Dignity 'as one of the ways to prepare future parents for childbirth and child care.

The aim of the work is to present the issues raised during antenatal education at the Birth School and during visits conducted by the community and midwife in Poland based on selected publications.

The transmission of information about the possibility of participating in the antenatal education results in an increase in the number of women and also on the occasion of future fathers preparing in a programmatic way for a delivery and taking correct parenting roles.
\end{abstract}

KEYWORDS: midwife, childbirth, pregnancy, maternity, prenatal education.

w domu pacjentki bądź podczas spotkań grupowych w prowadzonej przez położną szkole rodzenia.

Szkoła rodzenia jest formą edukacji przeznaczoną dla przyszłych rodziców oczekujących narodzin dziecka. To miejsce, w którym kobiety ciężarne oraz ich partnerzy mogą zdobyć kompleksową i niezbędną wiedzę z zakresu ciąży, porodu, połogu i opieki nad noworodkiem.

Omawiane przez położną zagadnienia powinny być oparte na wiedzy zdobytej podczas kształcenia akademickiego (dorobku nauk medycznych i humanistycznych), doświadczeniu zawodowym oraz kształceniu podyplomowym. Wiedza przekazywana kobietom i ich rodzinom powinna być przejrzysta i wolna od skomplikowanych sformułowań medycznych. Potencjał edukacji przedporodowej daje położnym możliwość wpływania na efektywną realizację zadań związanych 
z utrzymaniem zdrowia społeczeństwa [1, 4-5]. Położna poprzez prowadzenie spotkań edukacyjnych wypełnia założenia procesu edukacji pacjenta wynikające z Rozporządzenia Ministra Zdrowia z dnia 16 sierpnia 2018 roku w sprawie standardu organizacyjnego opieki okołoporodowej (Dz.U.2018 poz.1756) [6].

Szkoły rodzenia oraz porody rodzinne cieszą się coraz większą popularnością, na co zwracają uwagę autorzy zarówno w kraju, jaki i za granicą [7-9]. Na przygotowanie psychoprofilaktyczne zdobyte przez przyszłych rodziców w nowoczesnych szkołach rodzenia składają się wielokierunkowe zachowania prozdrowotne dotyczące ciąży, połogu, opieki nad noworodkiem, a przede wszystkim przygotowania do świadomego i aktywnego porodu, mającego na celu prawidłowe dotlenienie płodu w łonie matki oraz podczas porodu. Z badań Puszczałowskiej-Lizis i wsp. [10] wynika, że umiejętność zsynchronizowania oddechu z rytmem skurczów macicy w czasie porodu częściej posiadały kobiety uczęszczające na zajęcia szkoły rodzenia. Ponadto Kołomyjec i wsp. [11] wykazali, że poród wśród kobiet uczestniczących w kursie przedporodowym trwał średnio o 12 minut krócej w przypadku pierworódek oraz średnio o 16 minut krócej u wieloródek w stosunku do rodzących, które nie podjęły takiego rodzaju przygotowania.

W innych badaniach [12] wykazano, że niskie odczuwanie lęku u rodzącej uczęszczającej do szkoły rodzenia związany był z krótszym pobytem matki i noworodka w szpitalu oraz z wyższą punktacją Apgar u noworodka w chwili urodzenia. Bödecs i wsp. [13] wykazali zależność pomiędzy samooceną matek a urodzeniową masą noworodka oraz jego długością ciała. Ponadto położnice, które zakończyły kurs przedporodowy szybciej podejmowały się pielęgnacji noworodka w porównaniu do kobiet ciężarnych nieuczęszczających do szkoły rodzenia [14]. Wśród kobiet niepodejmujących edukacji przed - i poporodowej częściej obserwowano objawy zespołu baby blues pod postacią zmian nastroju, rozdrażnienia, bezradności, płaczliwości i zmęczenia [15].

\section{Cel pracy}

Celem pracy jest przybliżenie wybranych zagadnień poruszanych podczas edukacji przedporodowej w szkole rodzenia oraz na wizytach prowadzonych przez położną środowiskowo-rodzinną w Polsce na podstawie wybranych publikacji.

Poniżej przedstawiono zagadnienia najczęściej proponowane przez autorów prac opublikowanych w latach 2010-2019 na temat psychoprofilaktyki porodowej, redukcji lęku przez ciężarną czy podejmowania aktywności fizycznej w ciąży.

\section{Psychoprofilaktyka porodowa}

Ciąża i poród to wyjątkowe momenty w życiu kobiety. Mogłoby się wydawać, że chęć posiadania dziecka jest w dzisiejszych czasach decyzją o wiele bardziej świadomą i dojrzałą niż kilkanaście lat temu. Kobieta, która podejmuje taką decyzję, już na samym początku powinna podjąć odpowiednie kroki, by móc przejść przez okres ciąży, porodu i połogu w sposób świadomy i odpowiedzialny. Organizm kobiety potrzebuje około 3 miesięcy, aby zaakceptować to, co dzieje się z ciałem, aby pozbyć się szkodliwych substancji, tj. nikotyny oraz zgromadzić zapas potrzebnych witamin $[4,16]$.

Psychoprofilaktyka umożliwia przygotowanie kobiety ciężarnej do przeżywania ciąży i macierzyństwa w aspekcie fizjologicznym oraz psychicznym. Przygotowanie psychiczne i emocjonalne pozwala na przyswojenie zmian zachodzących w życiu kobiety podczas całej ciąży. Każda zmiana występująca w organizmie jest czynnikiem stresogennym, sytuacją wpływającą ujemnie na stan psychiczny. W psychice człowieka znaczącą funkcję pełnią emocje. To one współpracują między dwoma poziomami: podsystemem popędowo-emocjonalnym a podsystemem struktur poznawczych. Określają one także zorganizowanie i zachowanie człowieka na każdym etapie jego życia [10, 17]. Odpowiednie przygotowanie ciężarnej do porodu ułatwia edukacja przedporodowa i okołoporodowa.

Badania Gębicz i wsp. [9] przeprowadzone w szkole rodzenia przy Wielospecjalistycznym Szpitalu Wojewódzkim w Gorzowie Wielkopolskim wskazują na duże zainteresowanie obu płci edukacją przedporodową. Prowadzone zajęcia zgodne z programem edukacyjnym spełniały oczekiwania przyszłych rodziców, przyczyniając się do zdobycia wiedzy i umiejętności w zakresie ciąży, porodu i połogu. Modrzejewska i wsp. [18] sądzą, że uczestnictwo przyszłych rodziców w zajęciach szkoły rodzenia przekłada się na wzmocnienie więzi rodzicielskich. Ponadto szkoła rodzenia w sposób pragmatyczny przyczynia się do zmniejszenia obaw związanych z przebiegiem ciąży i porodu. Należy mocno podkreślić, że uczestnicy (100\% ankietowanych) zalecali wręcz przyszłym rodzicom odbycie kursu w szkole rodzenia [9].

\section{Redukcja lęku}

Uczestnictwo w zajęciach edukacji przedporodowej przekłada się na zmniejszenie lęku i stresu, które mogą pojawić się nie tylko podczas porodu, ale podczas każdego etapu ciąży. Negatywne emocje związane z niewiedzą mogą przyczynić się do ukończenia ciąży cięciem cesarskim [1, 3, 19]. Kobieta posiadająca wiedzę na temat przebiegu porodu łatwiej akceptuje nową sy- 
tuację i jest świadoma swoich działań. Potrafi wsłuchać się we własne ciało i rozpoznać objawy zapowiadającego się porodu. Zdobyta wiedza pozwala jej zrozumieć zaistniałą sytuację oraz pozytywnie ukierunkować swoje myśli. Pozwala także pozbyć się lęku i strachu, kobieta rozumie konieczność wykonywania zabiegów i niektórych czynności podczas porodu, dzięki czemu potrafi wyeliminować niepotrzebną panikę [10, 17, 19].

Zaobserwowano, że towarzyszący rodzącej lęk przed porodem jest przyczyną wzrostu napięcia w mięśniach i prowadzi do wzmożonego odczuwania bólu, czego konsekwencją jest nasilenie uczucia strachu i cierpienia. Dlatego tak ważne jest zapoznanie kobiety z fizjologią porodu i zachęcanie jej do czynnego udziału.

\section{Sposób na realizację aktywności fizycznej}

Aktywność fizyczna jest nieocenionym czynnikiem dla prawidłowego wzrostu, rozwoju oraz utrzymania fizjologicznych funkcji poszczególnych komórek i tkanek. Pomimo licznych rekomendacji i udowodnionych korzyści z podejmowanych ćwiczeń, większość kobiet od momentu zajścia w ciążę redukuje aktywność fizyczną. Wciąż odnotowuje się niezadowalający odsetek kobiet podejmujących aktywność fizyczną w ciąży, które tym samym obniżają własną sprawność fizyczną [3, 16].

Korzyści dla kobiet ciężarnych płynące z aktywności fizycznej są potwierdzone licznymi badaniami. American College of Obstetricians and Gynecologist (ACOG) pozytywnie ocenia aktywność fizyczną o umiarkowanej intensywności i zaleca regularne stosowanie ćwiczeń w celu podtrzymania prawidłowego stanu psychoruchowego [20]. Utrzymywanie sprawności fizycznej w czasie ciąży znacząco zapobiega rozwojowi cukrzycy ciążowej, szczególnie u otyłych kobiet. Wyniki badań epidemiologicznych wskazują, iż choroby układu naczyniowego są rzadsze, a co za tym idzie rzadziej stwierdza się występowanie obrzęków kończyn dolnych i żylaków. Adaptacja psychiczna kobiet ciężarnych - aktywnych fizycznie - do zmian zachodzących w ich ciele na skutek stosowanych ćwiczeń jest znacznie lepsza. Aktywność fizyczna zalecana jest jako profilaktyka stanów depresyjnych, które nadal są częstym zjawiskiem, bowiem dotyczą $14 \%$ do $23 \%$ populacji ciężarnych [21].

Szkoła rodzenia realizuje program obejmujący część teoretyczną i praktyczną, gdzie ćwiczenia fizyczne stanowią obszerną część zajęć. W opinii badaczy uczestnictwo kobiet w zajęciach szkoły rodzenia może być sposobem na utrzymanie aktywności fizycznej w ciąży, bowiem ciężarne uczestniczące w zajęciach wzajemnie się motywują do udziału w ćwiczeniach fizycznych [21]. W badaniach Branstaeter i wsp. [23] kobiety ciężarne najczęściej deklarowały aktywność fizyczną w postaci spaceru. Potwierdzają to również badania Ćwiek i wsp.
[22] oraz Wójtowicz [24]. Należy podkreślić, że aktywność fizyczna podejmowana podczas ciąży, prowadzona przez wykwalifikowany personel, jest bezpieczną formą realizacji aktywności fizycznej dla ciężarnej i przyczynia się do poprawy zarówno kondycji fizycznej, jak i samopoczucia, także uczy poprawnych technik oddychania i relaksacji [25].

\section{Budowanie poczucia bezpieczeństwa}

Istotne dla zdrowia i zachowania równowagi psychicznej kobiety ciężarnej jest poczucie bezpieczeństwa i świadomość stanu zdrowia płodu. Stan psychiczny ciężarnej wpływa na przebieg porodu, na jego charakter, stąd tak ważne jest odpowiednie przygotowanie rodzącej, ale również partnera do wejścia w zupełnie nowe role w ich życiu $[10,16]$.

Większość szkół rodzenia stawia sobie za cel udział w zajęciach praktycznych i teoretycznych nie tylko kobiety ciężarnej, ale również jej partnera. Uczą się oni akceptacji zmian zachodzących w ich życiu oraz tego jak przygotować się do tego ważnego okresu. Kobiety biorące udział w szkole rodzenia wykazują się większą wiedzą teoretyczną z zakresu porodu, połogu i opieki nad noworodkiem. Na sali porodowej znają najważniejsze medyczne zagadnienia, które mogą ich dotyczyć. Nie wpadają w panikę, gdy coś nie idzie po ich myśli - wiedzą, że w trakcie porodu sytuacja może się zmienić. Położna podczas zajęć omawia najważniejsze zagadnienia dotyczące pobytu w szpitalu - jakie kobieta ma prawa, czego może się domagać. To buduje jej pewność siebie oraz poczucie bezpieczeństwa. Zajęcia w szkole rodzenia pomagają też zwiększyć zaangażowanie partnera podczas porodu i opieki nad noworodkiem. Przyszły ojciec wie, jak może pomóc swojej partnerce podczas tej ważnej dla nich chwili. Pewniej podchodzi do pielęgnacji noworodka, ponieważ niektóre elementy pielęgnacji przećwiczył już na zajęciach praktycznych podczas kursu opieki przedporodowej [10, 26].

\section{Poród aktywny}

Pomimo że aktywny akt porodowy wynika tylko i wyłącznie z instynktu kobiety, większość rodzących potrzebuje praktycznego wsparcia w tym zakresie. Poród aktywny oznacza też wiarę w biologiczną zdolność każdej kobiety do urodzenia dziecka. W dzisiejszych czasach łatwego dostępu do leków i cięć cesarskich ważny jest powrót do porodów naturalnych, siłami natury kobiety [10].

Regularne spotkania z położną mają na celu zwiększenie świadomości i kreowanie prawidłowego wyobrażenia o porodzie, ale i o całym macierzyństwie. Celem zajęć przygotowanych dla ciężarnych jest zapoznanie ich z poszczególnymi etapami porodu, metodami natu- 
ralnej relaksacji, a przede wszystkim prawidłowego oddychania. Położne, fizjoterapeuci i trenerzy medyczni starają się wzmocnić jej wiarę we własne siły, utwierdzić w przekonaniu, że podczas porodu najważniejsza jest współpraca, a nie walka ze skurczami, bo dzięki tej współpracy już za chwilę rodząca ujrzy swoje nowo narodzone dziecko [10, 16].

Kobieta, która przy porodzie stara się być aktywna, postrzega siebie jako osobę w pełni zdrową, sprawną, a przecież właśnie o to chodzi [27].

\section{Rola położnej podczas edukacji przedporodowej}

Edukacja przedporodowa ma istotne znaczenie w przygotowaniu kobiety do roli matki. Położna podczas systematycznych spotkań uczy przyszłych rodziców, bardzo trudnego w początkowej fazie, nawiązywania kontaktu emocjonalnego z nienarodzonym dzieckiem. Wpaja przyszłym ojcom, że miłość dziecka do rodziców wcale nie płynie z mlekiem matki, a jest schematem działań i uczuć, które towarzyszą rodzicom na każdym etapie ciąży. Podczas zajęć kształtuje się prawidłowe postawy rodzicielskie oraz wzmacnia więź małżeńską. Odtąd dwoje ludzi zaczyna tworzyć rodzinę [10, 27].

Kobiety, które uczęszczały na zajęcia kursu przedporodowego twierdziły, że nabyta wiedza i praktyczne umiejętności dały im możliwość bardziej świadomego przeżywania okresu oczekiwania na narodziny dziecka $[19,26]$.

Szkoła rodzenia to instytucja, która stała się niezbędnym składnikiem organizacji opieki nad kobietami spodziewającymi się dziecka. Niezależnie od tego, w jaki sposób i gdzie kobieta chce rodzić, ważną rolę w porodzie naturalnym odgrywa położna. Staje się ona dla ciężarnej, a później i rodzącej przewodnikiem, który potrafi profesjonalnie pokierować akcją porodową i pomóc w początkowych trudach macierzyństwa $[5,10,17]$.

\section{Podsumowanie}

Uczestnictwo w zajęciach edukacji przedporodowej wpływa na redukcję lęku u kobiet spodziewających się pierwszego dziecka. Kobieta posiadająca wiedzę na temat ciąży i porodu przechodzi spokojniej przez hospitalizacje szpitalne, świadomie podejmując decyzje i potrafi odnaleźć się w nowej sytuacji. Położnice nie obawiają się pierwszego kontaktu z dzieckiem i mogą w pełni cieszyć się macierzyństwem.

\section{Piśmiennictwo}

1. Błachnio M, Dmoch-Gajzlerska E. Psychofizyczne przygotowanie do porodu wczoraj i dziś. Położ. Nauka Prakt. 2016; 2: 50-59.

2. Krysa J, Iwanowicz-Palus G, Bień A, Rzońca E, Zarajczyk M. Antenatal classes as a form of preparation for parenthood: analysis of benefits of participating in prenatal education. Zdr. Publ. 2016; 126: 192-196.

3. Bąk B, Mastalerz M. Effectiveness of childbirth classes in reducing anxiety before birth depending on age and education. Stud. Med. 2016; 32: 10-17.

4. Żelazko K, Szlączka A, Pałczyńska M, Jaros A. Ocena przygotowania ciężarnej do porodu i macierzyństwa przez Szkołę Rodzenia. Współcz. Pielęg. Ochr. Zdr. 2016; 5: 52-55.

5. Błachnio M, Dmoch-Gajzlerska E. Rola położnej jako andragoga w szkole rodzenia. Położ. Nauka Prakt. 2016; 1: 18-21.

6. Rozporządzenie Ministra Zdrowia z dnia 16 sierpnia 2018r. w sprawie standardu organizacyjnego opieki okołoporodowej. Dz.U.2018 poz.1756.

7. Auger SJ, Verbiest S, Spickard JV, Simán FM, Colindres M. Participatory group prenatal education using photonovels: Evaluation of a lay health educator model with low-income Latinas. J Particip Med. 2015; 7.

8. Guerreiro EM, Rodrigues DP, Queiroz AB, Ferreira Mde A. Health education in pregnancy and postpartum: meanings attributed by puerperal women. Rev Bras Enferm. 2014; 67: 1: 13-21.

9. Gębicz W, Plagens-Rotman K, Ulatowska A. Motywy uczestnictwa przyszłych rodziców w zajęciach edukacyjnych szkoły rodzenia. Piel Pol 2019; 3: 243-251.

10. Puszczałowska-Lizis E, Mokrzycka K, Jandziś S. Wpływ edukacji przedporodowej na przebieg ciąży, porodu i wczesne macierzyństwo. Medycyna Ogólna i Nauki o Zdrowiu 2016; 22: 264-269.

11. Kołomyjec P, Suchocki S, Kędra-Rakoczy M. Wykształcenie i zachowania prozdrowotne ciężarnych biorących udział w zajęciach szkoły rodzenia oraz ich wpływ na przebieg porodu i stan noworodka. Klin Perin Gin. 2007; 43: 57-60.

12. Consonni EB, Calderon IM, Consonni M, De Conti MH, Prevedel T.Ts, Rudge MV. A multidiscipinary program of preparation for childbirth and motherhood: maternal anxiety and perinatal outcomes. Reprod Health. 2010; 29: 28.

13. Bödecs T, Horváth B, Szilágyi E, Gonda X, Rihmer Z, Sándor J. Effects of depression, anxiety, self-esteem, and health behavior on neonatal outcomes in a population-based Hungarian sample. Eur J Obsetet Gynecol Reprod Biol. 2011; 1541: 45-50.

14. Kryszk B, Kaliwoda B, Sybilski AJ. Wpływ kształcenia w szkole rodzenia na postawy i zachowanie zdrowotne jej słuchaczy. Probl Lek. 2011; 47: 31-5.

15. Augustyniuk K, Rudnicki J, Grochans E, Jurczak A, WiederHuszla S, Szkup-Jabłońska M. Uczestnictwo w zajęciach Szkoły Matek i Ojców a częstość występowania zaburzeń emocjonalnych w okresie poporodowym. Med Og Nauk Zdr. 2013; 19: 138-41.

16. Małecka-Włoch A. Świadomość zdrowotna kobiet w okresie przedkoncepcyjnym i w czasie ciąży. Przegląd Lekarski 2015; 72: 49-52.

17. Piziak W. Wpływ przygotowania psychofizycznego w szkole rodzenia na przebieg ciąży i porodu. Przegląd Medyczny Uniwersytetu Rzeszowskiego 2009; 3: 282-292.

18. Modrzejewska E, Torbe A, Ćwiek D. Opinie położnej na temat udziału partnera w porodzie. Położna, Nauka i Profilaktyka 2015; 4: 8-13.

19. Szymański S, Brączyk W, Konstanty-Kurkiewicz V. Wpływ zajęć w szkole rodzenia na zmniejszenie lęku porodowego. Pielęg. Pol. 2017; 2: 232-235.

20. ACOG Committee Opinion number 267, 2002. Exercise during pregnancy and the postpartum period. American College of Obstetricians and Gynecologists. Obstet Gynecol 2002. 99: 171-173. 
21. Sass A, Maczka M. Szkoła rodzenia - sposób na realizacje aktywności fizycznej kobiet w ciąży? Hygeia Public Health 2013; 49: 359-364.

22. Ćwiek D, Szczęsna M, Malinowski W. Analiza aktywności fizycznej podejmowanej przez kobiety w czasie ciąży. Perinatol Neonatal Ginekol 2012; 5: 51-54.

23. Brantsaeter AL et al. Validation of self-reported recreational exercise in pregnant women in the Norwegian Mother and Child Cohort Study. Scand J Med Sci Sports 2009; 1-8.

24. Wójtowicz K, Krekora M, Krekora K, Biesiada L, Kędzierska A, Kolasa P, Krasomski G. Wpływ aktywności fizycznej ciężarnych na przebieg porodu. Kwart Ortop 2011; 2: 188-196.

25. Kwiatek M, Gęca T, Biegaj-Fic J, Kwaśniewska A. Szkoła rodzenia - profil pacjentek oraz wpływ zajęć na przebieg porodu i stan noworodka. MONZ, 2011;17: 111-115.

26. Sadowska M, Kędzierska A, Wdowiak A, Brześcińska A. Efektywność funkcjonowania szkół rodzenia w opinii kobiet. European Journal of Medical Technologies 2013; 1: 39-47.
27. Kicia M. Poród naturalny. Rozdz w: Praktyka położnej. Poród fizjologiczny. Red: Iwanowicz-Palus G, Wydawnictwo Raabe Lublin 2013. 3-13.

Artykuł przyjęty do redakcji: 20.08.2019.

Artykuł przyjęty do publikacji: 30.12.2019.

Źródło finansowania: brak.

Konflikt interesów: nie zadeklarowano.

\section{Adres do korespondencji:}

Katarzyna Plagens-Rotman

ul. Ks. Kard. Stefana Wyszyńskiego 38

62-200 Gniezno

e-mail: plagens.rotman@gmail.com

Państwowa Wyższa Szkoła Zawodowa im. Hipolita Cegielskiego w Gnieźnie 